\title{
HUBUNGAN POLA MAKAN DAN AKTIVITAS FISIK DENGAN STATUS GIZI PADA ANAK SEKOLAH DASAR DI SD NEGERI 47/IV KOTA JAMBI
}

\section{Relation Between Dietary Habit and Physical Activity With Nutritional Status Of Elementary School Students in SD Negeri 47/IV Jambi City}

\author{
Putri Octaviani ${ }^{1}$, M. Dody Izhar ${ }^{2}$, Andy Amir ${ }^{2}$ \\ ${ }^{1}$ Program Sarjana Studi Ilmu Kesehatan Masyarakat Universitas Jambi \\ ${ }^{2}$ Ilmu Kesehatan Masyarakat, Fakultas Kesehatan Masyarakat, Universitas Jambi
}

\begin{abstract}
Abstrak
Gizi dibutuhkan oleh anak sekolah untuk pertumbuhan dan perkembangan. Apabila masalah gizi pada anak tidak ditangani sedini mungkin, akan timbul masalah kesehatan di masa yang akan datang. Prevalensi anak dengan kategori kurus di Indonesia pada usia 6-12 tahun adalah 12,2\% dan gemuk sebesar 9,2\%, sedangkan tahun 2013 prevalensi anak dengan kategori pendek (TB/U) pada anak usia 5-12 tahun di Provinsi Jambi sebesar 29,7\%. Tujuan penelitian ini adalah untuk mengetahui hubungan antara pola makan dan aktivitas fisik dengan status gizi pada anak sekolah dasar di SD Negeri 47/IV Kota Jambi. Penelitian ini menggunakan pendekatan cross sectional. Populasi sebanyak 1.265 siswa dengan sampel sebanyak 60 siswa pada kelas IV dan V SD Negeri 47/IV Kota Jambi. Teknik sampel dengan menggunakan stratified proportionate random sampling, penelitian dilakukan 7 Mei s/d 21 Mei 2018. Adapun yang digunakan pada penelitian ini yaitu kuesioner Food Recall 2x24 jam dan PAQ-C. Analisis data dengan menggunakan uji fisher's exact test pada tingkat kepercayaan 95\% atau $\alpha=5 \%(\mathrm{p}<0,05)$. Hasil penelitian menunjukkan bahwa pola makan tidak berhubungan dengan status gizi pada anak dengan nilai $\mathrm{p}=0,069$. Terdapat hubungan antara aktivitas fisik dengan status gizi pada anak dengan nilai $\mathrm{p}=0,033$. Tidak terdapat hubungan yang bermakna antara pola makan dengan status gizi, namun terdapat hubungan yang bermakna antara aktivitas fisik dengan status gizi pada anak sekolah dasar di SD Negeri 47/IV Kota Jambi.
\end{abstract}

Kata Kunci: Pola Makan, Aktivitas Fisik, Status Gizi

\begin{abstract}
School-age children needs nutrition to grow and develop. There will be health issues, if this nutrition problem isn't handled as early as possible. The prevalence of underweight children in Indonesia at 6-12 years of age is $12.2 \%$ and fat is $9.2 \%$, whereas in 2013 , the prevalence of children in the short stature category (height/age) in children aged 5-12 years in Jambi Province was 29.7\%. The purpose of this study was to determine the relation between dietary habit and physical activity with nutritional status of elementary school students in SD Negeri 47/IV Jambi City. This study used a cross sectional approach. The population were 1,265 students with a sample of $604^{\text {th }}$ and $5^{\text {th }}$ grader students of SD Negeri $47 /$ IV Jambi City. Sample technique using stratified proportionate random sampling. The study was conducted from 7 May to 21 May 2018. Data were collected using a food recall 2x24 hours and PAQ-C questionnaire. Data analysis using fisher's exact test at $95 \%$ confidence level or $\alpha=5 \%$ ( $<<0.05)$. The results diet is not related to nutritional status in school students with a value of $\mathrm{p}=0.069$, however there is a relation between physical activity with nutritional status of elementary school students with a value of $\mathrm{p}=0.033$. There is no significant relation between dietary habit and nutritional status, but there is a meaningful relation between physical activity and nutritional status in elementary school children in SD Negeri 47 / IV Jambi City.
\end{abstract}

Keywords: Dietary Habit, Physical Activity, Nutritional Status

Korespondensi: Putri Octaviani

Email: putrioctaviani47@gmail.com 


\section{PENDAHULUAN}

Sampai saat ini gizi masih menjadi salah satu masalah kesehatan di Indonesia, tak terkecuali pada anak sekolah dasar. Permasalahan gizi yang sering dialami seperti gizi kurang dan gizi lebih, bila masalah gizi ini tidak ditangani sedini mungkin maka dapat berpengaruh pada kesehatan anak di masa yang akan datang. Seseorang dengan masalah gizi kurang umumnya disebabkan karena sosial ekonomi keluarga yang rendah, kurangnya persediaan pangan, kualitas lingkungan yang kurang baik, serta kurangnya pengetahuan masyarakat tentang gizi. Sedangkan masalah gizi lebih biasanya dikarenakan kurangnya pengetahuan seseorang tentang gizi seimbang, pola makan yang tidak baik, faktor genetik, serta apabila asupan makan terpenuhi namun kurang melakukan aktivitas fisik maka dapat memicu terjadinya overweight atau obesitas ${ }^{1}$.

Pada tahun 2015 prevalensi anak dengan kategori kurus di dunia sekitar 14,3\% atau sebanyak 95,2 juta anak ${ }^{2}$. Indonesia termasuk dalam kategori negara berkembang yang menyumbang sebesar $21,7 \%$ anak dengan kelebihan berat badan ${ }^{3}$. Menurut data provinsi Jambi tahun 2013 jumlah proporsi status gizi anak sangat pendek dan pendek yaitu sebesar $13,3 \%$ dan $16,5 \%{ }^{4}$. Masalah gizi pada anak sekolah dasar di Indonesia saat ini masih cukup tinggi, secara nasional prevalensi anak dengan kategori kurus pada usia 6-12 tahun adalah 12,2\%, sedangkan untuk kategori gemuk sebesar $9,2 \% 5$.

Apabila anak menderita kekurangan gizi maka dapat berpengaruh pada daya tangkap, konsentrasi belajar, pertumbuhan fisik menjadi tidak maksimal, pertahanan tubuh, struktur dan fungsi otak, serta perilaku menjadi terganggu. Pada masa perkembangan biologis anak membutuhkan makan dan minum dengan kualitas dan kuantitas yang memadai untuk membentuk fisik yang sempurna ${ }^{6}$.

Dengan adanya kantin selain untuk pemenuhan zat gizi dan nutrisi bagi pertumbuhan anak usia sekolah, kantin juga memiliki peranan penting dalam mewujudkan pesan-pesan kesehatan dan dapat menentukan perilaku makan siswa sehari-hari melalui penyediaan makanan jajanan di sekolah.

Salah satu faktor lain yang berhubungan dengan status gizi adalah aktivitas fisik. Berdasarkan penelitian sejenis yang dilakukan di SD Negeri Jatipuro I pada kelas IV dan V menyebutkan bahwa terdapat hubungan yang signifikan antara perilaku makan dan aktivitas fisik dengan status gizi pada anak usia sekolah ${ }^{7}$.

Menurut hasil penelitian Anggraini menyatakan bahwa terdapat hubungan yang bermakna antara tingkat aktivitas fisik dengan indek massa tubuh pada usia prasekolah ${ }^{8}$. Hasil penelitian ini sejalan dengan hasil penelitian yang menyebutkan bahwa anak dengan aktivitas fisik kurang cenderung memiliki berat badan yang lebih dibandingkan anak dengan aktivitas fisik sedang atau berat ${ }^{9}$.

Sesusai dengan anjuran dari Badan Kesehatan Dunia anak dan remaja usia 5 sampai 17 tahun membutuhkan aktivitas fisik setidaknya 60 menit dengan intesitas sedang hingga cukup berat setiap hari. Aktivitas fisik pada anak dipengaruhi oleh beberapa faktor seperti umur, jenis kelamin, dan pola makan. Memperbanyak aktivitas fisik di luar rumah dapat mengurangi risiko terjadinya kelebihan berat badan pada anak sekolah dasar ${ }^{2}$.

Penelitian Wilks menyebutkan bahwa tidak terdapat hubungan bermakna antara aktivitas fisik dengan massa lemak tubuh pada anak usia 4-11 tahun. Aktivitas fisik tidak dapat digunakan sebagai kunci penentu status gizi anak ${ }^{10}$.

Penelitian yang dilakukan oleh Johan juga menyebutkan bahwa aktivitas fisik tidak dapat 
mengurangi nilai dari indeks massa tubuh pada anak usia kurang dari 12 tahun $^{11}$. Namun berdasarkan penelitian lain menunjukkan bahwa aktivitas fisik memiliki hubungan yang signifikan dengan status nutrisi anak usia sekolah di SD BOPKRI Gondolayu Kota Yogyakarta $^{12}$. Status gizi merupakan kesehatan yang dihasilkan oleh keseimbangan antara kebutuhan dan masukan nutrisi ${ }^{13}$.

Terdapat perbedaan asupan energi antara laki-laki dengan perempuan dimana laki-laki cenderung lebih banyak membutuhkan asupan energi dibandingkan dengan perempuan dikarenakan laki-laki lebih banyak melakukan aktivitas fisik dibandingkan dengan perempuan. Hal ini tidak sejalan dengan penelitian yang dilakukan di Stockholm yang menyebutkan tidak ada perbedaan antara jenis kelamin dengan tingkat aktivitas fisik. Dimana waktu tidur mereka pada hari libur cenderung lebih sedikit dibandingkan hari kerja dan karena tingkat aktivitas mereka cenderung lebih banyak di luar rumah dengan keluarga pada saat hari libur ${ }^{14}$.

Dari banyaknya ekstrakurikuler tersebut menggambarkan banyaknya kegiatan yang menuntut anak terlibat aktif guna menunjang pertumbuhan dan perkembangan anak. Namun berdasarkan temuan peneliti, masih terdapat beberapa siswa yang tidak mengikuti ekstrakulikuler yang telah disediakan oleh pihak sekolah. Bahkan kadang-kadang nafsu makan pada anak usia sekolah menurun sehingga hal ini dapat menyebabkan makanan menjadi tidak seimbang dengan kalori yang diperlukan oleh tubuh atau dengan kata lain tidak sesuai dengan angka kecukupan gizi berdasarkan usia menurut jenis kelamin di Indonesia.

Berdasarkan latar belakang pola makan dan aktivitas fisik menjadi masalah gizi yang dapat mempengaruhi pertumbuhan dan perkembangan anak dimasa yang akan datang, maka dari itu peneliti tertarik untuk melakukan penelitian terkait "Hubungan Pola Makan dan Aktivitas Fisik Dengan Status Gizi Pada Anak Sekolah Dasar di SD Negeri 47/IV Kota Jambi”.

\section{METODE}

Pada penelitian ini menggunakan penelitian kuantitatif dengan pendekatan crosssectional. Pengambilan sampel dilakukan dengan menggunakan teknik stratified proportionate random sampling. Populasi dalam penelitian ini sebanyak 1.265 siswa, sampel sebanyak 60 siswa kelas IV dan V SD Negeri 47/IV Kota Jambi. Penelitian dilakukan dari tanggal 7 Mei sampai dengan 21 Mei 2018. Data dikumpulkan melalui wawancara dan pengukuran, ada pun yang digunakan pada penelitian ini yaitu kuesioner food recall 2x24 jam dan PAQ-C. Analisis data yang digunakan adalah analisis univariat dan bivariat dengan menggunakan uji fisher's exact test pada tingkat kepercayaan $95 \%$ atau $\alpha=5 \%(\mathrm{p}<0,05)$. Beberapa penelitian menunjukkan bahwa minimal food recall $2 \times 24$ jam tanpa berturutturut dapat memberikan gambaran asupan zat gizi lebih optimal dan memberikan variasi yang lebih besar tentang intake harian individu ${ }^{15}$.

\section{HASIL DAN PEMBAHASAN}

Karakteristik subjek penelitian meliputi kelompok usia, jenis kelamin, pendidikan orang tua, pekerjaan orang tua, dan penghasilan orang tua (tabel 1).

Berdasarkan tabel 1 diketahui bahwa distribusi usia, jenis kelamin, pendidikan orang tua, pekerjaan orang tua, dan penghasilan orang tua di SD Negeri 47/IV Kota Jambi Tahun 2018.

Pada tabel 2 diketahui bahwa distribusi responden berdasarkan asupan pola makan yang tersusun atas karbohidrat, protein, dan lemak di SD Negeri 47/IV Kota Jambi Tahun 2018. 
Pada tabel 3 diketahui bahwa dari 60 anak terdapat sebanyak $12(20 \%)$ anak dengan pola makan kurang dan sebanyak $48(80 \%)$ anak dengan pola makan cukup/lebih.
Sedangkan pada tabel 4 diketahui bahwa dari 60 anak terdapat sebanyak 33 (55\%) anak dengan aktivitas fisik kurang dan sebanyak 27 (45\%) anak dengan aktivitas fisik aktif.

Tabel 1. Karakteristik Responden Berdasarkan Usia, Jenis Kelamin, Pendidikan Orang Tua, Pekerjaan Orang Tua dan Penghasilan Orang Tua di SD Negeri 47/IV Kota Jambi Tahun 2018

\begin{tabular}{lcc}
\hline \multicolumn{1}{c}{ Karakteristik } & N & Persentase (\%) \\
\hline Usia & & \\
9 tahun & 19 & 31,66 \\
10 tahun & 28 & 46,66 \\
11 tahun & 13 & 21,66 \\
& & \\
Jenis Kelamin & 26 & 43,33 \\
$\quad$ Laki-laki & 34 & 56,66 \\
Perempuan & & \\
Pendidikan Orang Tua & 12 & 20,00 \\
$\quad$ Tamat SLTA & 14 & 23,33 \\
Tamat D3 & 29 & 48,33 \\
Tamat S1 & 5 & 8,33 \\
Tamat S2 & & \\
Pekerjaan Orang Tua & 28 & 46,66 \\
$\quad$ Pegawai Negeri/Swasta & 19 & 31,66 \\
Wiraswasta/Pedagang & 8 & 13,33 \\
TNI/POLRI & 5 & 8,33 \\
Buruh & & 33,33 \\
Penghasilan Orang Tua & 20 & 66,66 \\
$\quad$ < Rp 2.000.000,- & 40 & \\
> Rp 2.000.000,- & &
\end{tabular}

*Signifikan $(\mathrm{p}<0,05)$

Tabel 2. Distribusi Responden Berdasarkan Asupan Pola Makan di SD Negeri 47/IV Kota Jambi Tahun 2018

\begin{tabular}{lccc}
\multicolumn{1}{c}{ Usia } & \multicolumn{3}{c}{ Nilai Ukur (gram) } \\
& Min & Max & Mean \pm SD \\
\hline 7-9 Tahun (Lk \& Pr) & & & \\
$\quad$ Karbohidrat & 125 & 303 & $216,32 \pm 47,54$ \\
$\quad$ Protein & 48 & 87 & $67,63 \pm 10,90$ \\
$\quad$ Lemak & 48 & 135 & $80,84 \pm 21,95$ \\
10-12 Tahun (Laki-Laki) & & & \\
$\quad$ Karbohidrat & 116 & 389 & $266,61 \pm 83,17$ \\
$\quad$ Protein & 34 & 117 & $75,83 \pm 20,24$ \\
$\quad$ Lemak & 34 & 126 & $97,00 \pm 25,35$ \\
10-12 Tahun (Perempuan) & & & \\
$\quad$ Karbohidrat & 126 & 287 & $208,86 \pm 46,06$ \\
$\quad$ Protein & 39 & 107 & $60,04 \pm 15,95$ \\
$\quad$ Lemak & 44 & 106 & $74,13 \pm 17,53$ \\
\hline *Data Primer & & &
\end{tabular}

*Data Primer 
Tabel 3. Hubungan Pola Makan dengan Status Gizi (TB/U) Anak di SD Negeri 47/IV Kota Jambi Tahun 2018

\begin{tabular}{|c|c|c|c|c|c|c|}
\hline \multirow[b]{2}{*}{ Pola Makan } & \multicolumn{2}{|c|}{ Status Gizi (TB/U) } & \multirow{2}{*}{ Total } & \multirow[b]{2}{*}{ PR } & \multirow[b]{2}{*}{$\begin{array}{c}\text { CI } \\
(95 \%)\end{array}$} & \multirow{2}{*}{$\begin{array}{c}P_{-} \\
\text {Value }\end{array}$} \\
\hline & $\begin{array}{c}\text { Pendek } \\
\text { n }(\%)\end{array}$ & $\begin{array}{c}\text { Normal } \\
\text { n }(\%)\end{array}$ & & & & \\
\hline Kurang & $4(33,33)$ & $8(66,66)$ & $12(100)$ & \multirow[b]{2}{*}{3,20} & \multirow[b]{2}{*}{$\begin{array}{l}1,01- \\
10,13\end{array}$} & \multirow[b]{2}{*}{0,069} \\
\hline Cukup/Lebih & $5(10,41)$ & $\frac{43(89,58)}{51(85,00)}$ & $48(100)$ & & & \\
\hline
\end{tabular}

Tabel 4. Hubungan Aktivitas Fisik dengan Status Gizi (TB/U) Anak di SD Negeri 47/IV Kota Jambi Tahun 2018

\begin{tabular}{|c|c|c|c|c|c|c|}
\hline \multirow{2}{*}{$\begin{array}{c}\text { Aktivitas } \\
\text { Fisik }\end{array}$} & \multicolumn{2}{|c|}{ Status Gizi (TB/U) } & \multirow{2}{*}{ Total } & \multirow[b]{2}{*}{$\mathbf{P R}$} & \multirow[b]{2}{*}{$\begin{array}{c}\text { CI } \\
(95 \%)\end{array}$} & \multirow[b]{2}{*}{$\begin{array}{c}P- \\
\text { Value }\end{array}$} \\
\hline & $\begin{array}{c}\text { Pendek } \\
\text { n }(\%)\end{array}$ & $\begin{array}{c}\text { Normal } \\
\mathrm{n}(\%)\end{array}$ & & & & \\
\hline Kurang Aktif & $8(24,24)$ & $25(75,75)$ & $33(100)$ & \multirow{3}{*}{6,54} & \multirow{3}{*}{$\begin{array}{l}0,87- \\
49,12\end{array}$} & \multirow{3}{*}{0,033} \\
\hline Aktif & $1(3,70)$ & $26(96,29)$ & $27(100)$ & & & \\
\hline Total & $9(15,00)$ & $51(85,00)$ & $60(100)$ & & & \\
\hline
\end{tabular}

Berdasarkan tabel 3 diperoleh nilai $\mathrm{p}=$ 0,069 ( $p>0,05)$ hal ini menunjukkan tidak ada hubungan yang bermakna antara pola makan dengan status gizi pada anak sekolah dasar di SD Negeri 47/IV Kota Jambi.Secara statistik pola makan tidak berhubungan dengan status gizi dikarenakan nilai $\mathrm{p}>0,05$, tetapi berdasarkan nilai PR anak dengan pola makan kurang beresiko mengalami status gizi pendek 3,20 kali lebih besar dibandingkan anak dengan pola makan cukup/lebih $(\mathrm{PR}=3,20 ; 95 \%$ $\mathrm{CI}=1,01-10,13$ ).

Berdasarkan tabel 3 diperoleh nilai $\mathrm{p}=$ $0,033 \quad(\mathrm{p}<0,05)$ hal ini menunjukkan ada hubungan yang bermakna antara aktivitas fisik dengan status gizi pada anak sekolah dasar di SD Negeri 47/IV Kota Jambi. Berdasarkan nilai PR anak dengan aktivitas fisik kurang aktif beresiko mengalami status gizi pendek 6,54 kali lebih besar dibandingkan anak dengan aktivitas fisik aktif $(P R=6,54 ; 95 \%$ $\mathrm{CI}=0,87-49,12)$.

\section{Hubungan pola makan dengan status gizi pada anak sekolah dasar}

Berdasarkan hasil analisis bivariat diketahui bahwa dari 60 anak terdapat sebanyak $12(20,00 \%)$ anak dengan pola makan kurang dan sebanyak $48(80,00 \%)$ anak dengan pola makan cukup/lebih (tabel 3). Hasil uji fisher's exact test menunjukkan tidak ada hubungan yang bermakna antara pola makan dengan status gizi pada anak sekolah dasar di SD Negeri 47/IV Kota Jambi hal ini dibuktikan dengan nilai $\mathrm{p}=0,069$ ( $>>0,05)$ dan $\mathrm{PR}=3,20$ (95\% CI=1,01-10,13). Dengan kata lain, secara statistik pola makan tidak berhubungan dengan status gizi dikarenakan nilai $\mathrm{p}>0,05$, tetapi berdasarkan nilai PR anak dengan pola makan kurang beresiko mengalami status gizi pendek 3,20 kali lebih besar dibandingkan anak dengan pola makan cukup/lebih.

Berdasarkan teori, pola makan yang baik adalah makanan yang mengandung sumber zat 
pembangun, zat pengatur dan zat energi karena semua zat gizi diperoleh untuk pemeliharaan, partumbuhan, produktifitasi serta perkembangan otak di dalam tubuh. Penelitian oleh Lida menyatakan bahwa ada hubungan antara pola makan dengan status gizi anak usia prasekolah di PAUD Tunas Mulia Desa Claket Kecamatan Pacet Kabupaten Mojokerto, hal ini dikarenakan orang tua responden telah mengajarkan kebiasaan makan yang baik pada anak sejak kecil ${ }^{16}$. Penelitian yang dilakukan oleh Zulyastri juga menyebutkan bahwa ada hubungan antara pola makan pagi dengan status gizi siswa kelas 3, 4 dan 5 SD. Kurangnya asupan makanan yang masuk ke dalam tubuh dapat menyebabkan tidak terpenuhinya asupan nutrisi sehingga status gizi menjadi kurang ${ }^{17}$.

Penelitian oleh Purnamasari, dkk menyebutkan konsumsi gizi berhubungan erat dengan status gizi pada anak sekolah ${ }^{18}$.

Berdasarkan penelitian diketahui rata-rata asupan pola makan responden adalah cukup/ lebih, hal ini terlihat pada tabel $\mathbf{3}$ yang menyebutkan sebanyak 12 (20\%) orang dengan pola makan kurang, anak dengan pola makan cukup/lebih sebanyak 48 (80\%) orang. Pada anak usia 7-9 tahun (laki-laki dan perempuan) diketahui rata-rata kebutuhan karbohidrat di bawah AKG yaitu terdapat selisih sebesar 37,68 gram. Rata-rata kebutuhan protein dan lemak pada anak tersebut sebesar 18,63 gram dan 8,84 gram di atas AKG.

Pada anak usia 7-9 tahun (laki-laki dan perempuan) kurang mengkonsumsi makanan yang mengandung unsur karbohidrat seperti; nasi. Umumnya anak mengkonsumsi makanan yang kaya akan protein dan lemak (susu, telur, daging ayam, daging sapi, dendeng, udang, daging kambing dan ikan) yang membantu anak dalam konsentrasi belajar di sekolah, namun jika tidak diimbangi dengan asupan energi (nasi) maka anak akan cenderung cepat lelah dalam proses belajar tersebut. Suntari dan Widianah menyebutkan bahwa ada hubungan antara kalori sarapan pagi dengan kemampuan konsentrasi anak usia sekolah di SD Negeri 3 Canggu tahun 2012, hasil penelitian ini menyatakan anak yang mempunyai kalori sarapan pagi yang cukup cenderung memiliki konsentrasi yang baik daripada anak yang tidak cukup kalori sarapan pagi ${ }^{19}$.

Pada hasil penelitian, anak usia 10-12 tahun (laki-laki) diketahui rata-rata kebutuhan karbohidrat di bawah angka kecukupan gizi yaitu terdapat selisih sebesar 22,39 gram. Sedangkan rata-rata kebutuhan protein dan lemak pada kelompok usia anak tersebut sebesar 19,83 gram dan 27 gram di atas AKG. Sedangkan pada anak usia 10-12 tahun (perempuan) diketahui rata-rata kebutuhan karbohidrat di bawah AKG yaitu terdapat selisih sebesar 66,13 gram. Diketahui rata-rata kebutuhan protein dan lemak pada kelompok usia anak tersebut di atas AKG yaitu sebesar 0,04 gram dan 7,13 gram.

Terdapat selisih AKG pada unsur karbohidrat antara laki-laki dan perempuan dari penjelasan di atas. Dimana asupan energi pada laki-laki jauh lebih banyak dibandingkan dengan asupan energi pada perempuan yaitu selisih 43,74 gram. Hal ini didukung oleh penelitian Mumtahanah yang menyebutkan bahwa remaja laki-laki di wilayah Jakarta memiliki frekuensi konsumsi makan lebih sering dibandingkan dengan remaja perempuan dikarenakan remaja perempuan lebih mementingkan penampilan agar memiliki postur tubuh yang sempurna ${ }^{20}$.

Temuan penelitian yang dilakukan di SD Negeri 47/IV Kota Jambi diketahui bahwa rata-rata responden dalam penelitian ini menggunakan jasa catering. Menu makanan yang biasa disediakan oleh jasa catering yaitu; ayam sambal, tahu dan tempe serta sayur. 
Peneliti melakukan pengumpulan data selama 2 hari dan pada hari kedua dari 66 anak terdapat sebanyak 6 anak yang tidak hadir saat pengum-pulan data dikarenakan siswa sakit.

Pada umumnya faktor yang menentukan kuantitas makanan adalah tingkat pendapatan. Dari 60 responden, sebanyak 40 (66,66\%) anak diketahui penghasilan orang tua yang lebih dari Rp 2.000.000 (tabel 1). Tingginya pendapatan tidak selalu membawa perbaikan gizi pada konsumsi pangan hal ini dikarenakan tinggginya pendapatan belum tentu diikuti dengan peningkatan pengetahuan orang tua terkait kualitas pada makanan. Penghasilan yang meningkat berdampak pada perubahan pola konsumsi keluarga, dimana keluarga cenderung mengkonsumsi makanan yang berlemak tinggi dan siap saji (fast food). Apabila seseorang mengkonsumsi makanan berlemak tinggi dan tidak diimbangi dengan peningkatan konsumsi yang berserat tinggi (sayuran) maka akan terjadi penumpukkan timbunan lemak dalam tubuh atau dengan kata lain dapat terjadi kegemukan atau obesitas.

Menurut Berg pengetahuan mengenai ilmu gizi merupakan hal penting bagi kesehatan dan kesejahteraan seseorang. Terpenuhi atau tidaknya gizi seseorang tergantung dari kandungan gizi yang diperlukan bagi pertumbuhan yang optimal ${ }^{21}$. Menurut Aryanti terdapat hubungan antara pengetahuan gizi ibu dengan status gizi pada balita di Wilayah Kerja Puskesmas Sidoharjo Kabupaten Sragen $^{22}$.

Secara keseluruhan hasil penelitian ini bertolak belakang dengan teori yang mengatakan bahwa pola makan berhubungan dengan status gizi. Terdapat faktor lain yang mempengaruhi pola makan sehingga tidak berhubungan dengan status gizi pada anak sekolah dasar, yaitu penyakit infeksi dan sanitasi lingkungan. Temuan lain dalam penelitian ini yaitu didapati beberapa responden dalam penelitian ini memiliki kuku panjang dan tidak tersedianya sarana cuci tangan dengan sabun pada toilet dan wastafel. Hal ini didukung oleh penelitian Siregar yang mengatakan bahwa terdapat hubungan antara infeksi cacing terhadap pertumbuhan anak sekolah dasar ${ }^{23}$. Purnamasari, dkk menyebutkan bahwa sebanyak 48,5\% anak yang menjadi sampel dalam penelitian mengalami kecacingan. Hal ini menunjukkan infeksi cacing merupakan salah satu jenis infeksi yang perlu diwaspadai pada anak sekolah ${ }^{18}$.

Ada hubungan yang erat antara penyakit infeksi dengan kejadian malnutrisi. Terjadinya interaksi yang sinergis antara malnutrisi dengan kejadian infeksi akan mempengaruhi status gizi. Secara patologis misalnya; penurunan asupan zat gizi akibat berkurangnya nafsu makan, menurunnya absorbsi, dan tidak nafsu makan saat sakit, peningkatan kehilangan cairan atau zat gizi karena diare, mual atau muntah akibat perdarahan secara terusmenerus, meningkatnya kebutuhan akibat sakit dan parasit yang terdapat di dalam tubuh ${ }^{24}$.

Keadaan ini sejalan dengan penelitian Nikmah yang mengatakan bahwa tidak ada hubungan yang bermakna antara pola makan dengan status gizi anak prasekolah. Hal ini dipengaruhi oleh beberapa faktor seperti; tingkat kemampuan keluarga untuk menyediakan maka-nan masih rendah ${ }^{25}$.

Berdasarkan kajian dari beberapa hal tersebut di atas, maka pola makan tidak hanya sebagai determinan utama terhadap status gizi pada anak sekolah dasar di SD Negeri 47/IV Kota Jambi dikarenakan dalam penelitian ini asupan gizi anak tidak sebanding dengan angka kecukupan gizi.

Sehingga peneliti dapat menyimpulkan bahwa tidak terdapat hubungan yang bermakna antara pola makan dengan status gizi (TB/U) pada anak sekolah dasar di SD Negeri 47/IV Kota Jambi. 


\section{Hubungan aktivitas fisik dengan status gizi pada anak sekolah dasar}

Berdasarkan hasil analisis bivariat diketahui bahwa dari 60 anak terdapat sebanyak $33(55,00 \%)$ anak dengan aktivitas fisik kurang aktif dan $27(45,00 \%)$ anak dengan aktivitas fisik aktif (tabel 4). Hasil uji fisher's exact test menunjukkan ada hubungan yang bermakna antara aktivitas fisik dengan status gizi pada anak sekolah dasar di SD Negeri 47/IV Kota Jambi hal ini dibuktikan dengan nilai $\mathrm{p}=0,033(\mathrm{p}<0,05)$ dan $\mathrm{PR}=6,54(95 \% \mathrm{CI}$ $=0,87-49,12)$. Dengan kata lain, anak dengan aktivitas fisik kurang aktif beresiko mengalami status gizi pendek 6,54 kali lebih besar dibandingkan anak dengan aktivitas fisik aktif.

Berdasarkan teori, aktivitas fisik adalah segala kegiatan atau aktivitas yang menyebabkan peningkatan penggunaan energi atau kalori oleh tubuh $^{26}$. Hal ini tidak sejalan dengan penelitian Sofiyetti yang mengatakan bahwa tidak terdapat hubungan yang bermakna antara pola konsumsi dan aktivitas fisik dengan status gizi ${ }^{27}$. Penelitian Karnaeni, Mardatillah dan Heryanti menyebutkan tidak ada hubungan yang bermakna antara kebiasaan olahraga dengan status gizi ${ }^{28,29,30}$.

Pada penelitian ini, pengukuran aktivitas fisik menggunakan alat bantu PAQ-C. Umumnya kuesioner ini digunakan pada anakanak usia 8-14 tahun atau setara dengan kelas 4 sampai dengan kelas 8 . Penelitian ini menggunakan nilai mean sebagai cut off point untuk mengkategorikan dari 5 menjadi 2 kategori yaitu kurang aktif dan aktif. Apabila nilai total responden kecil dari nilai mean maka responden masuk dalam kategori kurang aktif, dan apabila nilai total responden lebih besar dari nilai mean maka responden masuk dalam kategori aktif ${ }^{31}$.

Berdasarkan pengolahan data, dari 60 anak diketahui bahwa terdapat sebanyak 33 $(55,00 \%)$ anak dengan aktivitas kurang aktif dan 27 (45,00\%) anak dengan aktivitas aktif. Pola aktivitas fisik yang tidak baik akan menyebabkan gangguan keseimbangan energi, dimana energi yang masuk lebih besar dibandingkan dengan energi yang keluar sehingga akan menyebabkan terjadinya penumpukkan lemak dan anak-anak akan kelihatan gemuk. Obesitas atau kelebihan berat badan masih menjadi permasalahan kesehatan di negara berkembang, dimana Indonesia setiap tahunnya menyumbang 21,7\% anak dengan kelebihan berat badan dan menurut data Riskesdas prevalensi anak dengan kategori gemuk sebanyak 9,2\% pada usia 6-12 tahun ${ }^{3,5}$.

Selain itu kurangnya aktivitas juga akan berpengaruh pada pertumbuhan tulang, masa tulang dan kelenturan tulang. Sehingga anakanak dengan aktivitas kurang akan mengalami gangguan dalam pertumbuhan tulangnya dengan kata lain pertumbuhan tulang menjadi tidak maksimal, dan muncul gangguan lain seperti terjadinya fraktur dan pengeroposan tulang karena komposisi tulang yang kurang. Dengan melakukan aktivitas fisik secara terusmenerus maka akan memicu hormon pertumbuhan tulang ${ }^{32}$.

Perubahan tulang yang disebabkan oleh aktivitas fisik dapat meningkatkan enzim tulang dan pembesaran pada tulang (bone hypertrophy). Untuk pembentukan tulang baru di dalam tubuh diperlukan rangsangan terusmenerus pada tulang, ibaratkan otot yang perlu dilatih supaya kuat ${ }^{33}$.

Berdasarkan kajian dari beberapa hal tersebut di atas, maka aktivitas fisik merupakan determinan utama terhadap status gizi pada anak sekolah dasar di SD Negeri 47/IV Kota Jambi dikarenakan banyak atau sedikitnya aktivitas fisik dapat mempengaruhi kebutuhan tubuh akan kalori sebagai energi. Namun apabila asupan energi melebihi kebutuhan dan tidak diimbangi dengan aktivitas fisik maka akan beresiko terjadinya 
obesitas pada anak dengan kata lain pertumbuhan anak akan menjadi tidak maksimal.

Sehingga peneliti dapat menyimpulkan bahwa terdapat hubungan yang bermakna antara aktivitas fisik dengan status gizi (TB/U) pada anak sekolah dasar di SD Negeri 47/IV Kota Jambi.

\section{KESIMPULAN DAN SARAN}

Dari 60 anak terdapat sebanyak $12(20 \%)$ anak dengan pola makan kurang dan 48 (80\%) anak dengan pola makan cukup/lebih. Selain itu diketahui bahwa terdapat sebanyak 33 (55\%) anak dengan aktivitas fisik kurang aktif dan 27 (45\%) anak dengan aktivitas fisik aktif.

Tidak terdapat hubungan yang bermakna antara pola makan dengan status gizi pada anak sekolah dasar di SD Negeri 47/IV Kota Jambi namun berdasarkan nilai PR anak dengan pola makan kurang beresiko mengalami status gizi pendek 3,20 kali lebih besar dibandingkan anak dengan pola makan cukup/lebih ( $\mathrm{p}=0,069 ; \mathrm{PR}=3,20 ; 95 \% \mathrm{CI}=$ 1,01-10,13).

Terdapat hubungan yang bermakna antara aktivitas fisik dengan status gizi pada anak sekolah dasar di SD Negeri 47/IV Kota Jambi. Berdasarkan nilai PR anak dengan aktivitas fisik kurang aktif beresiko mengalami status gizi pendek 6,54 kali lebih besar dibandingkan anak dengan aktivitas fisik aktif ( $\mathrm{p}=0,033$; PR $=6,54 ; 95 \% \mathrm{CI}=0,87-49,12)$. Hasil ini berarti semakin aktif anak melakukan aktivitas fisik maka akan semakin baik status gizinya.

Adapun saran yang dapat diberikan yaitu sebagai berikut; bagi dinas kesehatan dan puskesmas disarankan agar petugas gizi yang ada di puskesmas Simpang IV Sipin Kota Jambi melakukan kerja sama dengan pihak sekolah dengan memberikan sosialisasi berkala tentang pola makan yang seimbang dan aktivitas fisik untuk menunjang tumbuh kembang anak.
Bagi pihak sekolah; disarankan untuk mengaktifkan pemantauan pertumbuhan dan perkembangan pada anak sekolah, yaitu melalui guru UKS dan pembinaan dokter kecil yang ada di sekolah SD Negeri 47/IV Kota Jambi. Disarankan untuk mengaktifkan kegiatan ekstrakurikuler pada setiap anak sekolah dasar agar status gizi anak berada pada kondisi normal. Disarankan untuk memantau serta memonitong makanan yang dijual oleh pedagang kantin, serta jasa catering karena dapat mempengaruhi pola makan anak sekolah dasar dan disarankan untuk meningkatkan perilaku hidup bersih dan sehat pada anak sekolah dasar, khususnya sebelum menjamah makanan yaitu menyiapkan tempat cuci tangan dengan sabun pada air yang mengalir.

Bagi orang tua; disarankan untuk dapat meningkatkan aktivitas fisik anak di luar rumah dengan menambah aktivitas fisik seperti olahraga pada hari libur sekolah. Disarankan untuk menyediakan makanan yang bervariasi (karbohidrat, protein, lemak serta vitamin) demi terpenuhinya asupan gizi anak. Misalnya dengan menyediakan bekal makanan agar mengurangi perilaku konsumsi makanan yang tidak baik pada anak dan diharapkan untuk aktif mendapatkan informasi melalui media massa dan media sosial tentang pola makan yang sehat pada anak.

Bagi Peneliti Selanjutnya; disarankan untuk mengembangkan penelitian dengan metode yang berbeda (case-control) dan lainlain untuk meminimalisir bias yang terjadi pada variabel pola makan anak dikarenakan terbatasnya daya ingat akan riwayat makan subjek.

\section{DAFTAR PUSTAKA}

1. Almatsier, Sunita, Susirah Soetardjo, Moesijanti Soekatri. 2011. Gizi Seimbang 
Dalam Daur Kehidupan. Jakarta: Gramedia Pustaka Utama.

2. WHO. 2015. World Health Statistics. World Health Organization.

3. MDGs, Millenium Development Goals. 2013. Double Burden of Malnutrition.

4. [Balitbangkes] Badan Penelitian dan Pengembangan Kesehatan. 2015. Riset Kesehatan Dasar (Riskesdas) 2015. Jakarta: Kementrian Kesehatan RI.

5. Riset Kesehatan Dasar. 2010. Jakarta: Badan Penelitian dan Pengembangan Kesehatan, Kementrian Kesehatan RI.

6. Mulyadi. 2007. Peranan Gizi yang Berkualitas Dalam Mencegah Malnutrisi Pada Anak Sekolah Dasar. Jurnal Samudra Ilmu, 2007; 356-8.

7. Hapsari AI, Putu YA, Luh SA. 2011. Gambaran Status Gizi Siswa SD Negeri 3 Peliatan Kecamatan Ubud, Kabupaten Gianyar. FK Universitas Udayana.

8. Anggraini L. 2014. Hubungan Tingkat Aktivitas Fisik Terhadap Status Gizi Pada Anak Usia Prasekolah. Universitas Diponegoro.

9. Decelis, A., Jago, R., Fox, K.R. 2014. Physical Activity, Screen Time And Obesity Status In A Nationally Representative Sample Of Maltese Youth With International Comparisons, BioMed Central.

10. Wilks, DC., Sharp, JS., Ekelund Ulf., Thompson, GS., et al. 2011. Objectively Measured Physical Activity and Fat Mass in Children: A Bias-Adjusted MetaAnalysis of Prospective Studies. University of Swansea, United Kingdom. Phys Act, 2011:6 (2).

11. Johan.S. Lisal. 2006. Gangguan Makan pada Anak dan Remaja. J Med Nus. 2006; 27; 60-63.

12. Fitri, Yaumil. 2017. Hubungan Antara Aktivitas Fisik Dengan Status Nutrisi Anak Usia Sekolah di SD BOPKRI
Gondolayu Kota Yogyakarta. Skripsi. Yogyakarta: STIKes Jenderal Achkmad Yani.

13. Beck. E Mary. 2000. Nutrition and Dietics For Nurse. New York: Aspen Publisher

14. Ekstedt, M., Nyberg, G., M., Ekblom, Ö. \& Marcus, C. 2013. Sleep, physical activity and BMI in six to ten-year-old children measured by accelerometry: a cross-sectional study. Int J Behav Nurt Phys Act, 10 (1):1.

15. Sanjur., Diva., and Rodriguez, Maria.1997. Assesing Food Consumption (Selected Issues in Data Collection and Analysis). Division of Nutritional Sciences, Community Nutrition Program, College of Human Ecology, Comell University.

16. Lida, Khalimatus S. 2015. Hubungan Pola Makan Dengan Status Gizi Anak Pra Sekolah di PAUD Tunas Mulia Claket Kecamatan Pacet Mojokerto. Prodi Kebidanan STIKes Bina Sehat PPNI.

17. Zulyastri R, 2014. Hubungan pola makan pagi dengan status gizi siswa di SD Muhammadiyah Bendo Sranakan Bantul. Skripsi. Program Sudi Ilmu Keperawatan STIKes Aisyiyah Yogyakarta.

18. Purnamasari, DU, Dardjito E, dan Kusnandar. 2016. "Hubungan Jumlah Anggota Keluarga, Pengetahuan Gizi Ibu dan Tingkat Konsumsi Energi dengan Status Gizi Anak Sekolah Dasar.” Jurnal Kesehatan Indonesia. Vol. 08, (02) Juli. 2016.

19. Suntari, Ni, Y. Dan Widianah, L,. 2012. Hubungan Kalori Sarapan Pagi Dengan Kemampuan Konsentrasi Anak Usia Sekolah di SD Negeri 3 Canggu. Ilmu Keperawatan, FK Universitas Udayana, Bali. 
20. Mumtahanah, Siti. 2002. Gambaran Pola Konsumsi Makanan Siap Saji Pada Remaja di Dua Sekolah Lanjutan (SLTP) di Wilayah Jakarta Selatan. Skripsi. Depok: FKM UI.

21. Berg, A. 1986. Peranan Gizi dalam Pembangunan Nasional. Jakarta: CV Rajawali.

22. Aryanti, Marinda Adi. 2010. Hubungan Antara Pendapatan Keluarga, Pengetahuan Gizi Ibu, dan Pola Makan Dengan Status Gizi Balita di Wilayah Kerja Puskesmas Sidoharjo Kabupaten Sragen. Skripsi. Semarang: Universitas Negeri Semarang.

23. Siregar.,Charles, D. 2006. Pengaruh Infeksi Cacing Usus yang Ditularkan Melalui Tanah Pada Pertumbuhan Anak Usia 6-12 Tahun. Sari Pediatri Vo. 8 (2).

24. Supariasa, IDN., Bachyar B., dan Fajar I. 2012. Penilaian Status Gizi. Jakarta: Penerbit Buku Kedokteran EGC.

25. Nikmah. 2004. Hubungan Pola Makan Dengan Status Gizi Anak Balita Pada Keluarga Nelayan di Kelurahan Lappa Kecamatan Sinjai Utara Kabupaten Sinjai, Makassar. Skripsi. FKM Universitas Hasanuddin.

26. Afriwardi. 2011. Ilmu Kedokteran Olahraga. Jakarta: EGC

27. Sofiyetti. 2009. Hubungan Citra Tubuh, Pola Konsumsi, dan Aktivitas Fisik Dengan Status Gizi Pada Remaja Putri SMU Negeri 8 Batanghari Jambi. Skripsi. Depok: FKM UI

28. Karnaeni, Henny. 2005. Hubungan Antara Kebiasaan Konsumsi Makanan Cepat Saji Modern (Fast Food), Pola Aktivitas Fisik dan Faktor Lainnya Dengan Status Gizi Pada Remaja SMA Cakra Buana Depok. Skripsi. Depok: FKM UI

29. Mardatilah. 2008. Hubungan Kebiasaan Konsumsi Makanan Siap Saji Modern
(Fast Food, Aktivitas Fisik dan Faktor Lainnya dengan Kejadian Gizi Lebih pada Remaja SMA Islam PB Soedirman di Jakarta Timur Tahun 2008. Skripsi. Depok : FKM UI.

30. Heryanti, Evi. 2009. Kebiasaan Makan Cepat Saji (Fast Food Modern), Aktivitas Fisik dan Faktor Lainnya Dengan Status Gizi Pada Mahasiswa Penghuni Asrama UI. Skripsi. Depok: FKM UI.

31. Kowalski, K., Krocker, P., Donen, R. 2004. The Physical Activity Questionnaire for Older Children (PAQ$C)$. Canada : University of Saskatchewan. 32. Miftah. 2010. Cara Membuat Tubuh Anda Bisa Lebih Tinggi. Yogyakarta: Gaira Ilmu

33. Wiarto, G. 2013. Fisiologi dan Olahraga. Yogyakarta: Graha Ilmu. 